\title{
REPRESENTASI SUREALISME PADA VIDEO KLIP LAGU MAN UPON THE HILL KARYA STARS AND RABBIT
}

\author{
Nur Dwimas Setiawan ${ }^{1 *}$, Sri Wahyuningsih ${ }^{2}$ \\ ${ }^{1,2}$ Universitas Trunojoyo Madura, Bangkalan, Indonesia \\ *dwimsetiawan@gmail.com
}

\begin{abstract}
The music video for Man Upon The Hill by Stars and Rabbit can steal attention because it is able to present unique and interesting visuals. The purpose of this study was to determine the representation of the meaning of surrealism in the video clip Man Upon The Hill by Stars and rabbit. This research uses descriptive qualitative research methods. Data collection using the method of observation, indepth interviews, and documentation. Informants were selected using purposive sampling technique. The technique of checking the validity of the research data used the source triangulation technique. The result of this research is the relationship between humans and nature, representations of several scenes: First, symbols such as the pentagram have the meaning of a dimension of life. Second, the Third Eye Chakra is the highest consciousness. Third, the arrangement of roots to form a gate represents a gate to a different dimension. Fourth, the tree root guitar represents how nature communicates, the melody that sounds from nature. Fifth, the arrangement of floating stones in a circle is the cycle of life. Sixth, black skin is a representation of the balance of the life cycle. Seventh, women with horses represent warriors, children represent purity.
\end{abstract}

Keywords: Representation, Surrealism, Video Clips, Stars and Rabbit, Semiotics of Roland Barthes

\begin{abstract}
Abstrak
Video klip Man Upon The Hill yang dibawakan Stars and Rabbit dapat mencuri perhatian karena mampu menghadirkan visual yang unik dan menarik. Tujuan penelitian ini untuk mengetahui representasi makna surealisme pada video klip Man Upon The Hill Stars and rabbit. Penelitian ini menggunakan metode penelitian deskriptif kualitatif. Pengumpulan data menggunakan metode observasi, wawancara mendalam, dan dokumentasi. Informan dipilih dengan menggunakan teknik purposive sampling. Teknik pemeriksaan keabsahan data penelitian ini menggunakan teknik triangulasi sumber. Hasil peneliti ini adalah hubungan antar manusia dan alam. representasi dari beberapa scene: Pertama, simbol seperti pentagram memiliki makna sebuah dimensi kehidupan. Kedua, Third Eye Chakra merupakan kesadaran tertinggi. Ketiga, susunan akar membentuk gerbang merepresentasikan gerbang menuju perbedaan dimensi. Keempat, gitar akar pohon mewakili bagaimana alam berkomunikasi, melodi yang terdengar berasal dari alam. Kelima, susunan batu-batu melayang membentuk lingkaran merupakan siklus kehidupan. Keenam, kulit hitam merupakan representasi dari keseimbangan siklus kehidupan. Ketujuh, perempuan dengan kudanya merepresentasikan warrior, anak-anak merepresentasikan dari kemurnian.
\end{abstract}

Kata Kunci: Representasi, Surealisme, Video Klip, Stars and Rabbit, Semiotika Roland Barthes

\section{PENDAHULUAN}

Video klip merupakan suatu bentuk penyajian atau penyampaian dari sebuah lagu. Video klip merupakan sarana yang paling efektif dalam penyampaian pesan karena didukung dengang gambar dan suara atau musik yang dinyanyikan, ditambah tema yang yang disesuaikan dengan lirik lagu atau realitas sosial. Selain untuk promosi, video klip dianggap sebagai salah satu bentuk ekspresi sosial yang mana video klip merupakan media massa yang 
memperlihatkan realitas sosial dalam video klip tersebut. Melalui perkembangan teknologi ini pesan dapat disampaikan dengan mudah melalui video klip musik. Pada saat ini, Pencipta lagu dapat berkomunikasi dengan audiencenya melalui lirik lagu. Karena melalui lirik lagu, pencipta lagu ingin menyampaikan pesan yang merupakan pengekspresian dirinya terhadap fenomena-fenomena yang terjadi di sekitar. Banyaknya video klip musik di Indonesia maupun di dunia terdapat beberapa video klip yang menimbulkan pertanyaan serta opini-opini dari masyarakat khususnya bagi penikmat musik, seperti video klip Man Upon The Hill dari Stars and Rabbit yang menarik dan menimbulkan opini serta memiliki rasa penasaran akan makna yang sebenarnya. Mengadapatasi elemen musik etnik dan megusung dua tema, pertama tentang relasi manusia dan alam, kemudian tentang relasi antara manusia dan manusia dalam liriknya.

Video klip Man Upon The Hill dari Stars and Rabbit mencuri perhatian karena mampu menghadirkan visual yang unik dan menarik. Disisi lain, video klip Man Upon The Hill dianggap sangat kontroversial karena dalam video klip, Elda sang vokalis memiliki tiga mata satu di dahi yang menimbulkan banyak persepsi dan opini terhadap video klip yang disajikan dan tidak menutup kemungkinan terjadinya kesalahan dalam menafsirkan pesan yang terdapat dalam video klip tersebut. Jika diperhatikan, beberapa scene video klip ini divisualkan dengan efek mirror menampilkan pola tertentu dengan memperlihatkan simbol-simbol yang abstrak pastinya terdapat makna atau pesan yang ingin di sampaikan dalam video klip tersebut. Tidak ada penyampaian pesan secara langsung mengenai maksud yang sebenarnya dan mengenai tujuan pesan yang ingin disampaikan, dapat dilihat dari konsep surealisme pada setiap scene-nya. Namun yang lebih penting yaitu apakah tujuan dari penyampaian pesan tersebut melalui video klip telah terpenuhi. Video klip Man Upon The Hill ini menggambarkan berbagai karya visual yang memiliki makna dan makna tersebut tidak bisa diartikan dengan cara mengira-ngira. Pada video klip berbagai tanda muncul sekaligus, seperti visual, audio, dan teks, juga tanda yang terdapat dalam video klip Man Upon The Hill Stars and Rabbit.

Surealisme merupakan gerakan seni yang mula-mula tumbuh di Eropa dan kemudian meluas secara internasional. Surealisme pada awalnya dikaitkan dengan wacana psikoanalisis yang dikemukakan oleh Sigmund Freud, mengenai hal-hal yang irrasional, absurd, dan tidak logis. Surealisme juga merupakan gambaran ide tentang suatu ilusi yang absurd dan mengandung halusinasi, sehingga disebut sebagai hallucinatory realism. Secara etimologi, istilah surealis bertolak dari kata 'surreal' yang berarti ketidakbiasaan. Surealisme pada awalnya merupakan gerakan di wilayah sastra, suatu istilah yang digunakan oleh Apollinaire untuk dramanya di tahun 1917 (KBBI, 2020).

Istilah Semeiotics (dilafalkan demikian) diperkenalkan oleh Hippocrates (460-337 SM), penemu ilmu medis Barat, seperti ilmu gejala-gejala. Gejala, menurut Hippocrates, merupakan Semeion, bahasa Yunani untuk penunjuk (mark) atau tanda (sign) fisik. Dari dua istilah Yunani tersebut, maka semiotik secara umum didefinisikan dengan produksi tanda-tanda dan simbol-simbol sebagai bagian dari sistem kode yang digunakan untuk mengkomunikasikan informasi. Semiotik meliputi tanda-tanda visual dan verbal serta tactile dan olfactory (semua tanda atau sinyal yang bisa diakses dan bisa diterima oleh seluruh indera yang kita miliki) ketika tanda-tanda tersebut membentuk sistem kode yang secara sistematis menyampaikan informasi atau pesan secara tertulis di setiap kegiatan dan perilaku manusia (Sudarto, et.al., 2015). 
Semiotika, sebagaimana dijelaskan oleh Ferdinand de Saussure dalam Course in General Linguistics, adalah "ilmu yang mempelajari peran tanda sebagai bagian dari kehidupan sosial. Semiotika adalah ilmu yang mempelajari struktur, jenis, tipologi, serta relasi-relasi tanda dalam penggunaannya di dalam masyarakat (Piliang, 2012:47 dalam Kusuma \& Nurhayati, 2019) Berpijak dari pendapatnya tentang langue yang merupakan sistem tanda yang mengungkapkan gagasan ada pula sistem tanda alphabet bagi tuna wicara, simbol-simbol dalam upacara ritual, tanda dalam bidang militer. Saussure berpendapat bahwa langue adalah sistem yang terpenting. Oleh karena itu, dapat dibentuk sebuah ilmu lain yang mengkaji tanda-tanda dalam kehidupan sosial yang menjadi bagian dari psikologi sosial; ia menamakannya sémiologie. Kata tersebut berasal dari bahasa Yunani sēmeîon yang bermakna „tanda ${ }^{e e}$. Linguistik merupakan bagian dari ilmu yang mencakupi semua tanda itu. Kaidah semiotik dapat diterapkan pada linguistik (Lustyantie, 2012)

$\begin{array}{cc}\text { Semiotika } & \text { atau semiologi, } \\ \text { mempelajari } & \text { tentang }\end{array}$
kemanusiaan (humanity) memaknai hal-hal (things). Memaknai (to signify) dalam hal ini tidak dapat dicampuradukkan dengan mengkomunikasikan (to communicate). Semiotika merupakan suatu studi ilmu atau metode analisis untuk mengkaji tanda dalam suatu konteks skenario, gambar, teks, dan adegan menjadi sesuatu yang dapat dimaknai. Semiotika juga mempelajari semua yang berkaitan dengan tanda yang memungkinkan tanda-tanda tersebut memiliki arti atau makna yang tidak diketahui sebelumnya. Sebagai dasar penelitian semiotika, terdapat beberapa konsep dasar yang dapat dipahami, yaitu tanda atau simbol, kode, makna, dan mitos. Pada penelitian ini, peneliti memilih fokus penelitian pada tanda (signifier).

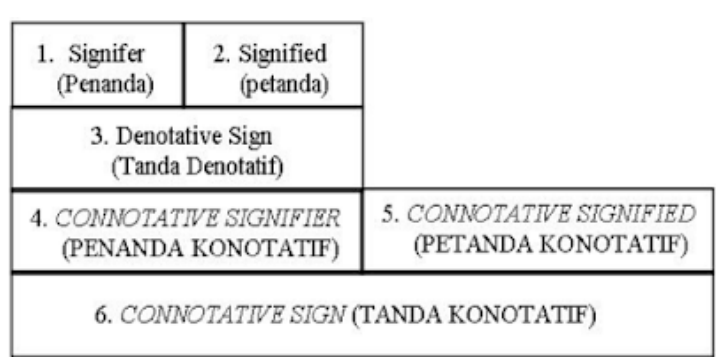

Gambar 1. Peta Tanda Roland Barthes Sumber : Cobley \& Jansz, 1999 dalam (Sobur, 2017:69)

Pada dasarnya makna denotatif meliput hal-hal yang ditunjuk oleh katakata. Makna denotatif merupakan makna yang sebenarnya dari suatu kata yang biasa kita temukan dalam kamus. Makna konotatif yaitu makna denotatif ditambah dengan segala gambaran, ingatan, dan perasaan yang ditimbulkan oleh sebuah kata tersebut dan ketika indera yang dimiliki bersinggungan dengan petanda. Sehingga akan menjadi interaksi saat petanda bertemu dengan perasaan atau emosi dari pembaca serta sebuah nilai-nilai dari kebudayaannya.

Konotasi yang identik dengan operasi ideologi dalam kerangka Barthes disebut dengan mitos, dan memiliki fungsi untuk mengungkapkan dan memberikan suatu pembenaraan bagi nilai-nilai yang dominan dan berlaku dalam suatu periode tertentu. Mitos memiliki tugas untuk memberikan justifikasi ilmiah kepada kehendak sejarah, dan membuat kemungkinan tampak abadi. Terdapat pola tiga dimensi dalam mitos, yakni penanda, petanda, dan tanda.

Terdapat dua hal yang berkaitan dengan representasi. Pertama bagaimana seseorang atau gagasan ditampilkan dalam suatu pesan media bila dikaitkan dengan realitas yang ada. Kedua, bagaimana eksekusi penyajian objek tersebut dalam media. Eksekusi representasi objek tersebut terdapat dalam pemilihan kata, kalimat, dan penguatan dengan foto atau imaji macam apa yang akan digunakan untuk menampilkan seseorang atau gagasan dalam pemberitaan (Eriyanto, 2001:113). 
Representasi adalah penggunaan bahasa untuk menyampaikan sesuatu yang berarti kepada orang lain. Representasi merupakan kegunaan dari tanda. Proses merekam ide, pengetahuan, atau pesan dalam beberapa cara fisik disebut representasi.

Video klip, iklan, fotografi, film animasi, acara televisi merupakan diantara bentuk-bentuk komunikasi visual, yang pastinya memiliki pesan-pesan tertentu yang disampaikan oleh director kepada audience. Desain komunikasi visual adalah sebuah sistem semiotika khusus dengan perbendaharaan tanda dan sintaks yang khas yang membuat hal ini berbeda dengan semiotika seni (Piliang, 2010:339)

Peneliti berfokus pada "Bagaimana representasi surealisme yang ada di dalam video klip Man Upon The Hill dari Stars and Rabbit?". Penelitian ini bertujuan untuk mengetahui representasi makna surealisme pada video klip lagu Man Upon The Hill Stars and rabbit, sehingga terungkap apa tujuan dari penyampaian video klip tersebut yang sarat akan makna.

Penelitian terdahulu yang menjadi acuan dari peneliti ini antara lain: Pertama, penelitian yang berjudul Analisis Semiotika Roland Barthes Pada Video Klip Rehat Oleh Kunto Aji (dalam Ainsyah S, 2019) berbeda dengan penelitian yang akan diteliti oleh peneliti yang berjudul Representasi Surealisme Pada Video Klip Man Upon The Hill Stars and Rabbit perbedaanya terletak pada fokus penelitian yang terdapat pada kedua penelitian tersebut. Pada video klip Man Upon The Hill yang dibawakan group band Stars and Rabbit memiliki daya tarik tersendiri bagi peneliti karena setiap scene pada video klip tersebut dapat membuat rasa penasaran akan arti sesungguhnya pada adegan yang mengandung unsur seni surealisme. Kedua, penelitian yang berjudul Analisis Semiotika Pada Video Klip Man Upon The Hill Stars and Rabbit oleh Anggy Rusidi, Universitas Negeri Padang, 2019 (Anggy, 2019).
Terdapat perbedaan antara penelitian tersebut dengan penelitian yang ditulis peneliti, perbedaan terletak pada objek penelitian, pada penelitian yang berjudul Analisis Semiotika Pada Video Klip Man Upon The Hill Stars and Rabbit objeknya hanya berfokus pada pemaknaan visual pada video klip tersebut sedangkan pada penelitian peneliti yang berjudul Representasi Surealisme Pada Video Klip Man Upon The Hill Stars And Rabbit objek penelitiannya adalah media video klip yang diantaranya scene-scene yang merepresentasikan surealisme dan cukup jelas bahwa penelitian peneliti konsep yang digunakan adalah representasi dan memfokuskan pada scene yang mengandung unsur surealisme.

\section{METODOLOGI}

Paradigma Penelitian dalam penelitian ini adalah paradigma Konstruktivis. Paradigma konstruktivis melihat suatu realita dibentuk oleh berbagai macam latar belakang sebagai bentuk konstruksi realita tersebut. Realita yang dijadikan sebagai objek penelitin merupakan suatu tindakan sosial oleh aktor sosial. Paradigm konstruktivis bertujuan untuk memahami apa yang menjadi konstruksi suatu realita. Oleh karena itu peneliti harus dapat mengetahui faktor apa saja yang mendorong suatu realitas dapat terjadi dan dapat menjelaskan bagaimana faktor-faktor tersebut merekonstruksi realita tersebut (Pujileksono, 2015:28-29)

Penelitian ini menggunakan jenis penelitian deskriptif kualitatif. Penelitian ini biasanya menggunakan analisis dan penjabaran dari data-data hasil observasi. Penelitian kualitatif betujuan untuk memberikan pemahaman mengenai bagaimana dan mengapa sehubungan dengan realitas atau gejala yang diteliti dan juga mengemukakan gambarannya (Pawito, 2007:101).

Metode penelitian yang digunakan dalam penelitian ini menggunakan analisis 
semiotika. Semiotika berasal dari kata semiotik diperkenalkan oleh salah satu filsuf terkenal Yunani yaitu Hippocrates (460-337 SM). Menurut Hippocrates mengatakan bahwa semeion, bahasa Yunani untuk penunjuk (mark) atau tanda (sign) fisik. Dari dua istilah Yunani tersebut, maka semiotik secara umum didefinisikan dengan produksi tanda-tanda dan simbolsimbol sebagai bagian dari sistem kode yang digunakan untuk mengkomunikasikan informasi. Semiotik meliputi tanda-tanda visual dan verbal serta tactile dan olfactory (semua tanda atau sinyal yang bisa diakses dan bisa diterima oleh seluruh indera yang kita miliki) ketika tanda-tanda tersebut membentuk sistem kode yang secara sistematis menyampaikan informasi atau pesan secara tertulis di setiap kegiatan dan perilaku manusia (y 766) dalam (Thoriq, 2019). Analisi semiotika memiliki teori tersendiri. Salah satu teorinya yaitu teori Roland Barthez (1915-1980).

Roland Barthez mengembangkan semiotika menjadi dua tingkatan utama, yaitu denotasi dan konotasi. Kata konotasi berasal dari bahasa latin connotare atau "menjadi makna" dan mengarah pada tanda-tanda kultural yang terpisah dengan sebuah kata. Kata ini dapat merupakan simbol-simbol, historis, dan yang berhubungan dengan emosional. Barthes juga melihat aspek lain yaitu mitos. Mitos menurutnya akan menjadi penanda baru. Tanda ini berkaitan akan sesuatu yang memiliki makna konotasi kemudian berkembang menjadi denotasi dan makna denotasi tersebut menjadi mitos (Barthes, 2017)

Objek penelitian merupakan permasalahan yang dikaji atau permasalahan yang di investigasi dalam penelitian (Sugiyono, 2016:38). Objek penelitian dalam penelitian ini adalah representasi surealisme pada video klip Man Upon The Hill khususnya scene-scene yang merepresentasikan surealisme yang terdapat pada video klip Man Upon The Hill Stars and Rabbit.

Subjek penelitian merupakan orang (informan) yang memberi informasi kepada peneliti tentang data yang diharapkan dan juga relevan dengan penelitian yang dilakukan. Subjek dalam penelitian ini adalah grup duo Stars and Rabbit tersebut.

Penentuan informan pada penelitian ini menggunakan teknik purposive sampling, yaitu teknik pengambilan sampel didasarkan atas pertimbangan tertentu atau orang (informan) yang termasuk kriteria sebagai sampel (Sugiyono, 2016:85).

Sumber data bertujuan untuk memperoleh suatu informasi yang diperlukan atau dibutuhkan. Dengan melakukan wawancara dan pengamatan atau observasi adalah salah satu cara untuk mendapatkan suatu informasi yang diperlukan agar penelitian ini bisa atau dapat terselesaikan dengan adanya informasi dari sumbernya langsung dan melakukan observasi data. Sumber data yang akan digunakan dalam penelitian ini adalah data primer dan data sekunder.

Sumber data primer merupakan sumber data yang langsung memberikan data kepada pengumpul data (Sugiyono, 2016:137). Pada penelitian ini, untuk mendapatkan data primer peneliti melakukan pengamatan pada video klip Man Upon The Hill terlebih dahulu kemudian melakukan wawancara langsung dengan pencipta lagu yang memiliki ide atas konsep video klip Man Upon The Hill yaitu pencipta lagu juga sekaligus vokalis dari Stars and Rabbit guna untuk mendapatkan atau menghimpun suatu informasi yang dibutuhkan peneliti untuk mengetahui makna surealisme yang terkandung dalam video klip tersebut.

Sumber data sekunder di dapat dari berbagai jurnal, skripsi maupun karya tulis berupa website dan informasi-informasi yang ada berupa buku, e-book, dan internet yang pastinya berkaitan dengan penelitian 
yang akan dilaksanakan guna menambah informasi ataupun memperkaya tulisan.

\section{HASIL DAN PEMBAHASAN}

Hasil temuan dari penelitian yang dilakukan oleh peneliti terkait video klip
Man Upon The Hill karya dari Stars and Rabbit dengan cara men-capture dan kemudian menampilkan beberapa scene yang menurut peneliti dianggap mengandung unsur surealisme.

Tabel 1

Deskripsi Scene-1

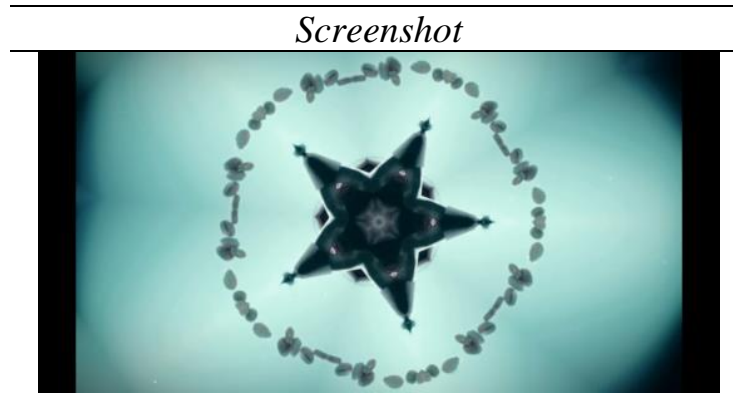

Gambar 1 (sumber: youtube)

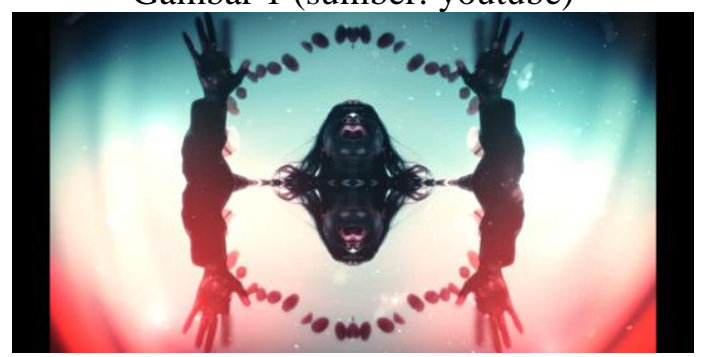

Gambar 2 (sumber: youtube)

Tampak pada visual pemeran wanita menari-nari dengan visualisasi mirror effect (efek cermin) sehingga membentuk atau menyerupai simbol pentagram. Tampak juga susunan batu melayang yang membentuk sebuah lingkaran.

\section{Penanda}

Pada gambar 2 di tabel 1, terlihat sekilas seseorang perempuan bernyanyi dan menari-nari dengan tarian layaknya penari tradisional memainkan tangannya dengan lentik, melambailambai dan juga warna kulit gelap yang cenderung hitam seperti bayangan yang sedang menari. Pada gambar 1 tampak suatu bentuk hasil dari tarian yang dilakukan seorang perempuan yang ada pada gambar tersebut dan batu-batu yang melayang dan melingkar.

\section{Petanda}

Pemeran perempuan yang ada pada video klip tersebut adalah Elda Suryani yang sekaligus juga vokalis dari Stars and Rabbit. Pada adegan di scene pertama tampak Elda dengan kulit yang berwarna hitam menyerupai bayangan dan sedang benyanyi dan menari-nari dengan lambaian tangan yang lentik. Suara vokal Elda pada scene pertama terdengar sangat mistis dikarenakan nada yang keluar dari mulut Elda sama halnya seperti suara alam dan suara-suara yang mungkin juga menjadi suara yang biasanya terdapat pada lantunan-lantunan kegiatan adat pada suku tertentu. Pengambilan gambar medium close up menunjukkan bahwa agar penonton terfokus pada objek yang terdapat dalam video klip tersebut. Kemudian gerakan tarian yang dihasilkan Elda membentuk suatu simbol pentagram karena pada adegan tersebut sutradara video klip Man Upon The Hill menggunakan visual yang menarik dipadukan dengan mirror effect yang menjadikan gerakan tarian tersebut membentuk suatu simbol yang menyerupai pentagram. Hal ini menjadi sebuah petunjuk kepada pentonton akan makna 
dari adegan tersebut.

\section{Makna Denotasi}

Pada adegan atau scene pertama, Elda sedang melantunkan nyanyian dan melakukan gerakan tarian, kulitnya pun gelap cenderung hitam menyerupai bayangan yang sedang menari dan tampak juga susunan batu yang membentuk sebuah lingkaran.

\section{Makna Konotatif}

Adegan atau scene-1 pada video klip Man Upon The Hill dapat dilihat Elda sebagai pemeran perempuan dalam adegan tersebut bernyanyi dan juga melakukan gerakan tarian-tarian dipadukan dengan mirror effect sehingga membentuk sesuatu simbol yang menyerupai pentagram dan juga terdapat susunan batu melayang yang membentuk suatu lingkaran yang bermakna dimensi kehidupan, susunan batu melayang yang membentuk sebuah lingkaran hampir sama dengan gerbang (gate) yang terbentuk oleh akar yang berada diatas bukit.

Dari analisis konotatif diatas kesimpulannya bahwa adegan tersebut merepresentasikan sebuah dimensi dalam kehidupan yang berkaitan dengan suatu keadaan dimana belum terjadi diskoneksi antara alam dan manusia, seakan-akan menggambarkan sebuah cinta yang utuh

\section{Tabel 2}

Deskripsi Scene-2

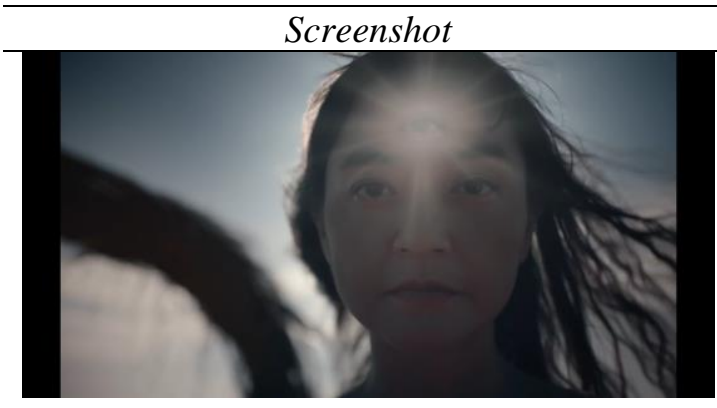

(sumber: youtube)

\section{Keterangan}

Pada siang hari seorang perempuan berambut panjang dengan wajah merenung berdiri dekat sebuah gerbang (gate) yang terbuat dari akar. Tampak pada dahi diantara kedua mata perempuan tersebut sebuah mata yang memancarkan cahaya putih bersinar.

\section{Penanda}

Pada gambar tampak terlihat perempuan berambut panjang berdiri dengan baju yang sedikit telanjang dada dekat sebuah gerbang yang terbuat dari akar pohon, perempuan tersebut terlihat seperti merenung memikirkan suatu hal. Perempuan itu berdiri dekat sebuah gerbang diatas bukit dengan angin yang kencang sehingga membuat rambut perempuan tersebut berterbangan. Tampak juga pada dahi perempuan 
itu diantara kedua matanya terselip satu titik yang menyerupai mata yang bercahaya putih terang.

\section{Petanda}

Siang hari diatas bukit, Elda berdiri dekat sebuah gerbang (gate) yang terbuat dari akar pohon. Pengambilan gambar pada scene ini yakni close up dan medium close up yang menunjukkan situasi dan kondisi emosi yang terfokus kepada wajah Elda yang sedang merenung dan lebih terfokus lagi kepada mata yang terletak pada dahi Elda yang mengeluarkan cahaya dan bersinar. Maksud dari pengambilan gambar close up dan medium close up pada adegan tersebut bertujuan untuk memfokuskan kepada objek yakni Elda yang memiliki mata ketiga yang terletak di dahinya di tengah-tengah diantara kedua matanya. Hembusan angin yang membuat rambut Elda berterbangan semakin menambah kesan dramatis dan menunjukkan bahwa ada suatu pesan yang ingin disampaikan dari mata ketiga tersebut.

\section{Makna Denotasi}

Siang hari diatas bukit, Elda berdiri dekat sebuah gerbang yang terbuat dari akar pohon. Elda seperti sedang merenungkan sesuatu, angin yang berhembus membuat rambut Elda berterbangan. Tampak terlihat terdapat mata yang terletak di dahi Elda diantara kedua matanya bercahaya dan memancarkan sinar.

\section{Makna Konotatif}

Pada gambar dapat dilihat bahwa pengambilan gambar close up dengan maksud memfokuskan pada mata yang terletak di dahi Elda diantara kedua matanya. Adanya mata yang terletak di dahi merupakan simbol dari Third Eye Chakra atau Chakra Mata Ketiga, menandakan sesuatu yang berhubungan dengan terbukanya intuisi dari seseorang ketika berada dekat dengan alam dan menunjukkan kesadaran tertinggi (higher consciousness), dengan kata lain ketika kesadaran seseorang lebih tinggi daripada kesadaran orang normal pada umumnya atau juga bisa dikatakan mata jiwa manusia yang telah melebihi batas normal dari suatu hal yang wajar manusia lihat, kesadaran tentang semesta yang diatur oleh satu energi, hubungan manusia dengan alam dan tuhan yang maha penyayang juga menunjukkan salah satu jalan spiritual (spiritual journey) seseorang. 


\begin{tabular}{ll}
\hline & bahwa mata yang terletak di dahi \\
merepresentasikan nafsu dan akal yang di dapat & dari kedua mata manusia menjadi hati yang \\
melihatnya berubah menjadi rohani dan sebuah & perjalanan spiritual tentang ketenangan, damai, \\
refleksi diri dan merasakan semua yang ada di & alam semesta selalu bersama tuhan hingga semua \\
hal dianggapnya sama yakni anugerah dari Allah & dan kasih sayang sesama makhluk ciptaan-Nya. \\
& Pada dasarnya setiap manusia memiliki Chakra \\
Mata Ketiga hanya saja kebanyakan orang tidak \\
menyadarinya ataupun orang tersebut tidak \\
mengerti bahwa dirinya telah menggunakan \\
Chakra Mata Ketiga yang dia miliki
\end{tabular}

Tabel 3

Deskripsi Scene-3

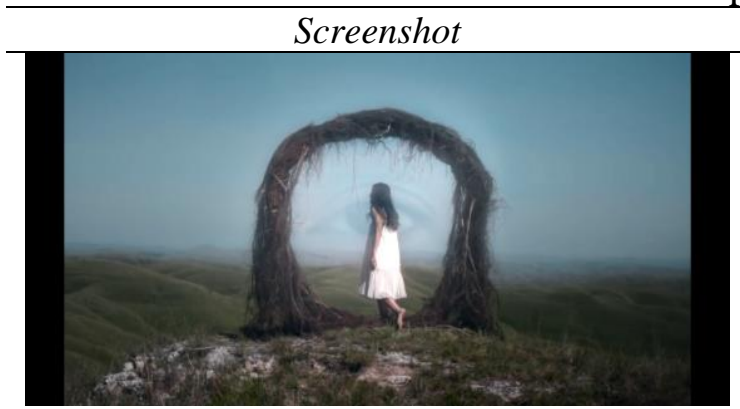

(sumber: youtube)
Keterangan

Siang hari diatas bukit, seorang perempuan sedang berjalan menuju sebuah gerbang (gate) yang terbuat dari akar pohon.

\section{Penanda}

Pada gambar terlihat seorang perempuan diatas bukit berada di puncak tertinggi pada siang hari berambut panjang menggunakan blouse tangtop midi berwarna putih dan tidak memakai alas kaki sedang berjalan menuju gerbang yang terbuat dari akar pohon. Tampak juga terlihat sebuah mata yang berada di tengah gerbang tersebut.

\section{Petanda}

Pada siang hari di puncak tertinggi diatas sebuah bukit, Elda berjalan menuju gerbang (gate) yang terbuat dari akar pohon. Elda tampak terlihat seperti penasaran dan ingin memasuki gerbang tersebut, tanpa alas kaki Elda pun berjalan mendekati gerbang tersebut. Terlihat sebuah mata yang berada di tengah gerbang yang akan dilalui Elda itu menandakan bahwa gerbang tersebut bukan gerbang sembarangan dan pastinya memiliki makna atas keberadaan mata di tengah-tengah gerbang tersebut. Teknik pengambilan gambar menggunakan teknik long shot/landscape dengan maksud menunjukkan keberadaan objek secara keseluruhan di suatu temoat dimana adegan tersebut terjadi yang menunjukkan bahwa Elda berada di alam terbuka dan posisi gerbang yang terbuat dari akar pohon yang akan dilalui Elda berada di puncak tertinggi diatas sebuah bukit. Terlihat 
juga langit yang membentang dan perbukitan yang indah menunjukkan bahwa alam semesta sangatlah luas dan ingin menunjukkan bahwa kekuasaan tuhan yang telah menciptakan alam semesta dan ingin menunjukkan bahwa manusia terlihat sangat kecil dihadapannya.

\section{Makna Denotasi}

Siang hari di puncak tertinggi diatas bukit, tampak Elda sedang berjalan tanpa menggunakan alas kaki menuju sebuah gerbang yang terbuat dari akar pohon. Elda berjalan menuju gerbang tersebut seperti orang yang sedang kebingungan dan juga penasaran akan keberadaan gerbang tersebut. Tampak juga langit yang cerah dan perbukitan hijau yang asri ditempat Elda berada.

\section{Makna Konotatif}

Pada gambar dapat dilihat terdapat sebuah gerbang (gate) yang terbuat dari akar pohon dan berada di puncak tertinggi diatas bukit dan Elda berjalan menuju gerbang tersebut. Susunan akar pohon yang membentuk gerbang (gate) yang merupakan portal atau pintu gerbang menuju perbedaan dimensi. Hal ini dapat dilihat dalam video klip tersebut, pemeran perempuan dalam video klip yakni Elda itu sendiri dan pemeran laki-laki yang diperankan oleh Adi berada dalam dunia yang sama tetapi mereka tumbuh dan berkembang dengan jalannya masing-masing ditandai dengan adanya portal atau pintu gerbang (gate) yang terbuat dari akar pohon dan pada video klip tersebut digambarkan seolaholah tidak bertemu lagi.

Dari analisis konotatif diatas kesimpulannya bahwa susunan akar yang membentuk gerbang (gate) merepresentasikan sebuah portal atau pintu gerbang menuju perbedaan dimensi, maksudnya adalah perbedaan dimensi antara kehidupan laki-laki dan perempuan yang ada dalam video klip tersebut 
Tabel 4

Deskripsi Scene-4

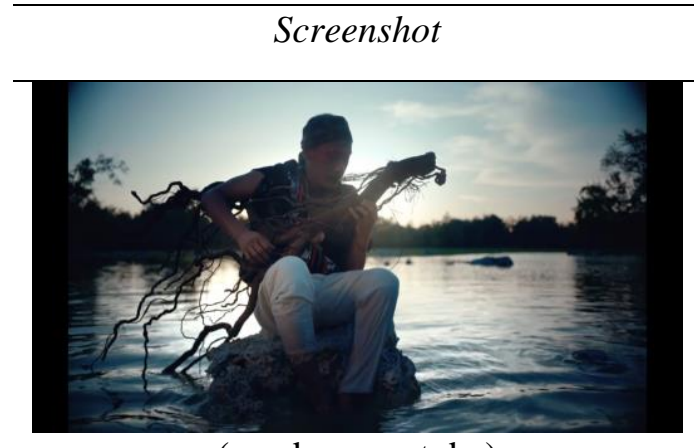

(sumber: youtube)
Keterangan

Pada siang hari diatas batu yang terletak di sungai, terlihat seorang laki-laki sedang memainkan gitar yang terbuat dari akar pohon.

\section{Penanda}

Pada gambar terlihat seorang laki-laki menggunakan pakaian lengan seperti rompi kemudian memakai celana putih dan juga menggunakan penutup kepala pada siang hari sedang duduk diatas batu yang dikelilingi air seperti sedang berada di sungai. Tampak laki-laki tersebut memainkan layaknya sebuah gitar dan terlihat aneh karena gitar yang dimaksud berbeda dengan gitar pada umumnya yakni gitar yang dimainkan terlihat terbuat dari akar pohon.

\section{Petanda}

Di sungai pada siang hari, terlihat Adi duduk diatas batu yang berada diatas sungai tersebut. Adi terlihat sangat menghayati dalam bermain gitar. Ada yang terlihat berbeda dari biasanya, bentuk gitar yang pada umumnya yang sering kita lihat berbeda dengan gitar yang dimainkan Adi, gitar yang dimainkan terbuat dari akar pohon. Adi menggunakan akar pohon layaknya dia sedang memainkan sebuah gitar. Kemudian, terlihat dalam scene tersebut Adi seorang diri dan tidak ada orang lain sedang memainkan gitar duduk diatas sebuah batu karang yang berada di sungai. Teknik pengambilan gambar (angle) menggunakan teknik long shot dengan tujuan ingin menunjukkan keberadaan objek secara keseluruhan di suatu tempat dimana adegan tersebut terjadi sekaligus menunjukkan latar belakang pada scene tersebut (background) yakni air (sungai), tumbuhan, dan juga langit, karena manusia memang selalu hidup berdampingan dengan alam.

\section{Makna Denotasi}

Adi yang hanya seorang diri duduk diatas batu yang berada di sungai menggunakan pakaian seperti rompi dan menggunakan celana panjang putih juga menggunakan penutup kepala atau bandana tanpa alas kaki sedang memainkan akar pohon yang terlihat layaknya seperti gitar.

\section{Makna Konotatif}

Pada gambar tampak Adi duduk diatas batu yang berada disungai dan sedang memainkan gitar yang 
terbuat dari akar pohon, akar pohon itu sendiri merupakan salah satu benda yang ada di alam. Angle kamera yang digunakan adalah teknik long shot dengan maksud ingin menunjukkan bahwa latar belakang atau background dari adegan tersebut adalah memperlihatkan bagian dari alam yakni air dan tumbuhan.

Dari analisis konotatif diatas kesimpulannya bahwa konsep pada scene tersebut merepresentasikan bahwa manusia bersatu secara harmonis dengan alam. Semua melodi yang manusia dengar berasal alam. Elemen-elemen alam yang terdapat di dalamnya seperti air dan bumi, juga ingin menunjukkan keindahan alam ciptaanNya.

Tabel 5

Deskripsi Scene-5

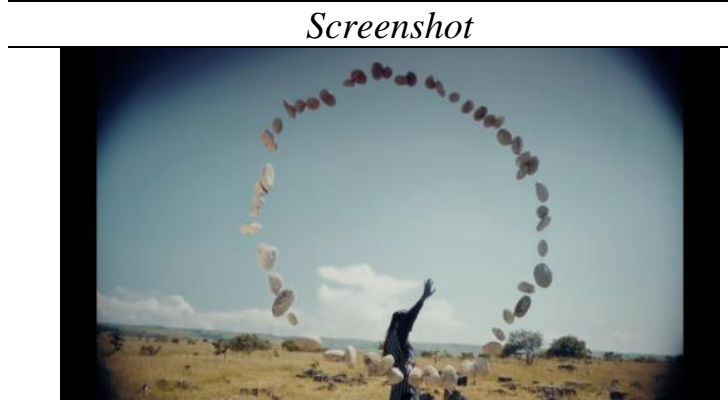

(sumber: youtube)
Pada siang hari di sebuah dataran padang rumput yang juga terdapat batu-batuan, tampak seorang perempuan berjalan sambil mengangkat tangannya mengitari susunan batu yang melayang dan membentuk lingkaran

\section{Penanda}

Pada gambar siang hari di padang rumput terlihat seorang perempuan menggunakan pakaian berwarna hitam putih bergaris sedang berjalan mengelilingi susunan batu-batu melayang yang membentuk lingkaran sambil mengangkat tangannya. Tampak seorang perempuan berkulit hitam seperti sedang menari dan background susunan batu melayang yang membentuk lingkaran.

\section{Petanda}

Tampak Elda sedang berjalan mengelilingi susunan batu-batu melayang yang membentuk lingkaran sambil mengangkat tangannya seakanakan ingin melakukan sesuatu terhadap lingkaran batu tersebut atau hanya ingin sekedar berkomunikasi. Pengambilan gambar menggunakan teknik medium close up menunjukkan sesuatu yang terfokus kepada objek yakni keberadaan susunan batu-batu melayang yang membentuk lingkaran. Kemudian Elda menari dengan latar belakang susunan batu-batu tersebut dengan ditambahkan efek cermin (mirror effect) menambah kesan 
dramatis.

\section{Makna Denotasi}

Pada siang hari di padang rumput, Elda sedang berjalan mengelilingi susunan batu-batu melayang yang membentuk lingkaran. Terlihat aneh, karena batu-batu tersebut berbeda dengan biasanya yakni batu-batu tersebut melayang dan membentuk lingkaran hal itu hanya terjadi di dunia khayalan dan tidak akan mungkin terjadi di dunia nyata. Kemudian juga terlihat Elda mengangkat salah satu tangannya mengarah ke lingkaran batu tersebut dan terlihat Elda sedang menari dengan latar belakang (background) yang sama yaitu susunan batu yang melingkar tersebut.

\section{Makna Konotatif \\ Terlihat pada scene tersebut Elda sedang berjalan mengelilingi susunan batu yang melayang dan membentuk lingkaran. Meskipun hal tersebut sangat tidak mungkin terjadi di dunia nyata akan tetapi dalam video klip tersebut batu yang melayang dan membentuk lingkaran seperti memiliki makna ataupun arti yang ingin disampaikan kepada penonton (audience). Susunan batu yang melayang dan membentuk lingkaran merupakan cycle of life atau siklus kehidupan dan hal itu berkaitan dengan spiritual journey setiap orang. \\ Dari analisis konotatif diatas kesimpulannya bahwa terdapat unsur yang membuat penonton berpikir akan maksud dari hal tersebut. Pada scene tersebut terdapat susunan batu-batu yang melayang dan membentuk lingkaran yang merupakan siklus kehidupan dan batu-batuan juga termasuk salah satu dari elemen alam sedangkan Elemen-elemen alam yang ada salah satunya batu (bumi) menggambarkan spiritual journey atau perjalanan spiritual sesorang.}

Tabel 6

Deskripsi Scene-6

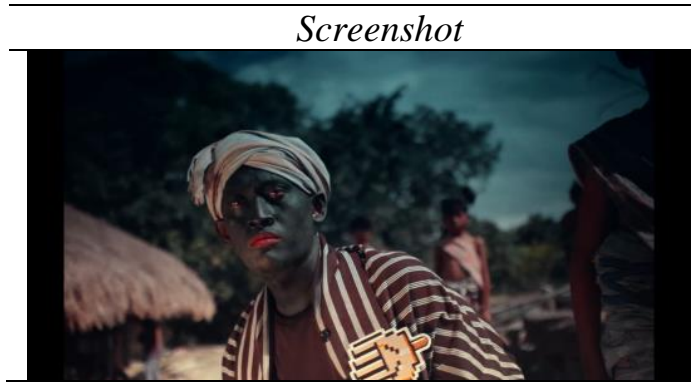

\section{Keterangan}

Tampak seorang laki-laki berkulit hitam menggunakan pengikat kepala dan menggunakan baju hitam putih bergaris.

\section{Penanda}

Pada gambar terlihat seorang laki-laki menggunakan ikat kepala seperti surban 

dengan motif bergaris berwarna hitam putih dan memiliki keunikan yang berbeda dengan manusia pada umumnya karena memiliki warna kulit yang gelap cenderung hitam sedang berjalan didepan anak-anak dengan tatapan serius dengan latar belakang rumah adat desa.

\section{Petanda}

Tampak Adi yang menjadi pemeran laki-laki dalam video klip tersebut menggunakan penutup kepala seperti surban dan menggunakan pakaian bergaris hitam putih. Uniknya, dalam video klip tersebut seluruh badan Adi di make up body painting berwarna hitam yang memberi kesan bahwa kulit hitam atau gelap identik dengan warna kulit suku masyarakat Indonesia timur. Terlihat beberapa anak-anak yang berdiri di belakang Adi dan juga rumah adat desa Waingapu sebagai latar belakangnya. Pengambilan gambar menggunakan teknik close up menunjukkan sesuatu yang lebih terfokus kepada objek (Wahyuningsih, 2019:19), yakni laki-laki dengan warna kulit yang gelap cenderung hitam.

\section{Makna Denotasi}

Pada gambar tampak seluruh badan Adi di make up body painting berwarna hitam sehingga terlihat aneh dan berbeda dengan kulit manusia pada umumnya. Kemudian Adi menggunakan penutup kepala berwarna putih dan pakaian bergaris hitam putih. Terlihat juga bebrapa anak yang sedang berdiri dibelakang Adi menggunakan pakaian adat desa tersebut dan juga tampak rumah adat pada latar belakang scene tersebut.

\section{Makna Konotatif}

Terlihat pada scene tersebut Adi yang berada disebuah halaman rumah dan seluruh badannya di make up body painting berwarna hitam memiliki maksud dan tujuan tertentu. Memang terlihat aneh, Adi yang seluruh badannya di painting warna gelap yang cenderung hitam sama sekali tidak ada kaitannya dengan ras dari masyarakat Sumba khususnya Waingapu.

Dari analisis konotatif diatas kesimpulannya bahwa laki-laki berkulit gelap cenderung hitam dalam video klip Man Upon The Hill merupakan representasi dari keseimbangan siklus kehidupan, dan lebih mengangkat kepada 
perspektif dualisme hitam atau putih, gelap atau terang, manusia tidak akan bisa menghargai terang jika tidak ada gelap, dualisme dapat membantu manusia untuk melihat makna yang lebih dalam dari situasi dalam kehidupan.

\section{Tabel 7}

\section{Deskripsi Scene-7}

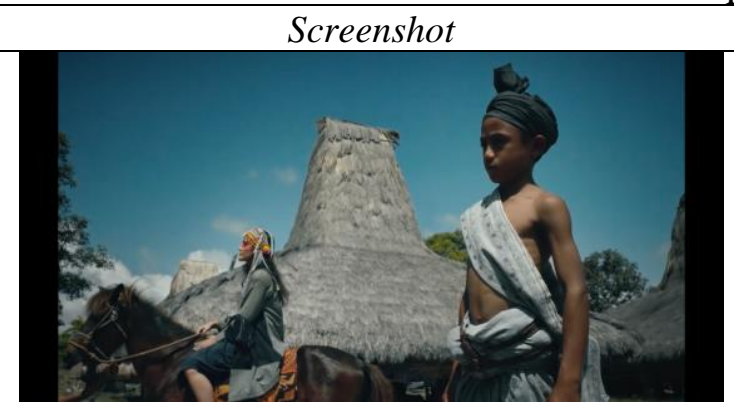

Gambar 1 (sumber: youtube)

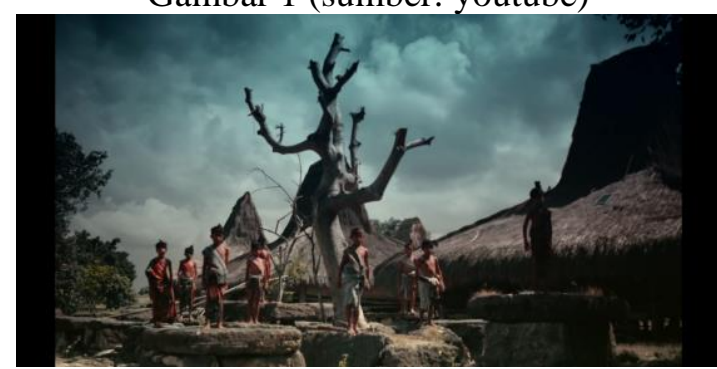

Gambar 2 (sumber: youtube)
Keterangan

Siang hari di sebuah desa di Waingapu, terlihat seorang perempuan menunggangi seekor kuda dan seorang anak kecil berdiri di sebelah perempuan tersebut. Kemudian beberapa anak terlihat berdiri diatas batu dan juga duduk berkumpul dengan menggunakan pakaian adat desa Waingapu.

\section{Penanda}

Pada gambar 1, tampak seorang perempuan berambut panjang dengan menggunakan ikat kepala sambil menunggangi seekor kuda yang gagah dan tinggi besar. Kemudian terlihat juga seorang anak kecil berdiri disebelah perempuan yang menunggangi kuda dengan tatapan mata yang tajam.

Pada gambar 2, terlihat beberapa anak kecil berdiri diatas sebuah batu yang besar dan juga duduk berkumpul menggunakan pakaian adat dengan latar belakang (background) rumah adat dari desa tersebut.

\section{Petanda}

Pada gambar 1, terlihat Elda sedang menunggangi kuda dan disampingnya terlihat seorang anak kecil masyarakat desa Waingapu berdiri dekat Elda yang berada diatas kuda, tatapan mata keduanya sangat tajam seakan sedang menghadapi sesuatu, Pengambilan gambar pada gambar 1 menggunakan teknik two shot menunjukkan aktivitas apa yang dilakukan oleh kedua objek dan juga menunjukkan suatu hubungan kedekatan antara kedua objek.

Pada gambar 2, tampak beberapa anak kecil yang berdiri di atas batu, sama halnya seperti gambar 1 yang tatapan matanya tajam seakan sedang menghadapi sesuatu. Pengambilan gambar pada gambar 2 menggunakan teknik long shot dengan tujuan ingin menunjukkan keberadaan objek secara keseluruhan di suatu tempat dimana adegan tersebut terjadi. 


\section{Makna Denotasi}

Siang hari di sebuah desa, Elda menunggangi kuda dan disampingnya terdapat seorang anak kecil dan juga terdapat beberapa anak kecil berdiri di atas batu besar dengan menggunakan pakaian adat desa Waingapu.

\section{Makna Konotatif}

Terlihat adegan Elda sedang menunggangi kuda yang gagah dan tinggi besar, kemudian juga terdapat seorang anak berada tepat disamping Elda juga beberapa anak yang ada pada scene tersebut dengan menggunakan pakaian adat desa Waingapu. Adegan ini menggambarakan konsep layaknya seorang pejuang, karena budaya dari suku-suku yang ada di Indonesia terkadang menggunakan alat transportasi berupa hewan kuda untuk melakukan sesuatu dan hal tersebut terlihat pada Elda yang sedang menunggangi kuda seakan-akan dirinya adalah pejuang diperkuat oleh seorang anak yang berdiri di sampingnya.

Dari analisis konotatif diatas kesimpulannya bahwa adegan Elda yang sedang menunggangi kuda merepresentasikan bahwa Elda adalah seorang warrior atau pejuang, pendekar dan pemimpin. Kemudian juga seorang anak yang berdiri berdekatan bersama Elda yang menunggangi kuda dengan tatapan tajam, memiliki makna bahwa karakter seorang anak dalam scene tersebut adalah seorang anak yang pemberani. Terlihat juga beberapa anak-anak yang ada dalam scene tersebut. Anak-anak yang terdapat dalam scene tersebut dapat dikatakan merepresentasikan kemurnian, kesucian atau purity karena sejatinya anak-anak masih suci dan bersih dari hal-hal buruk dan ketika manusia kembali ke alam sama halnya manusia tersebut menjadi seperti anak-anak yang kembali kepada "IBU"nya (alam).

Terdapat pola tiga dimensi dalam mitos, yakni penanda, petanda, dan tanda. Sebagai suatu sistem yang unik, mitos dibangun oleh suatu suatu rantai pemaknaan tataran kedua. Pada mitos, sebuah petanda memiliki beberapa penanda (Sobur, 2017:71)

\section{Tabel 8}

Simbol Menyerupai Pentagram pada Scene-1

Signifier Merupakan representasi dari sebuah ruang dimensi dalam kehidupan
yang berkaitan dengan suatu keadaan dimana belum terjadi diskoneksi 


\begin{tabular}{ll}
\hline & antara alam dan manusia. (form) \\
\hline Signified & $\begin{array}{l}\text { Peristiwa atau kejadian dalam perjalanan waktu yang mana antara alam } \\
\text { dan manusia saling berkaitan. (concept) }\end{array}$ \\
\hline Signification & $\begin{array}{l}\text { Menggambarkan sebuah cinta yang utuh atau selaras antara alam dan } \\
\text { manusia. }\end{array}$ \\
\hline
\end{tabular}

Tabel 9

Third Eye Chakra pada Scene-2

\begin{tabular}{ll}
\hline Signifier & $\begin{array}{l}\text { Merupakan representasi dari nafsu dan akal yang di dapat dari kedua } \\
\text { mata manusia menjadi hati yang melihatnya berubah menjadi rohani dan } \\
\text { sebuah perjalanan spiritual tentang ketenangan, damai, refleksi diri. } \\
(\text { form })\end{array}$ \\
\hline Signified & $\begin{array}{l}\text { Terbukanya intuisi dari seseorang ketika berada dekat dengan alam dan } \\
\text { menunjukkan kesadaran tertinggi yakni kesadaran yg telah melebihi batas } \\
\text { normal dari suatu hal yang wajar manusia lihat. (concept) }\end{array}$ \\
\hline Signification & $\begin{array}{l}\text { Memberikan persepsi diluar penglihatan biasa, dan juga merupakan } \\
\text { konsep mistik tentang mata yang tidak kasat mata. }\end{array}$ \\
\hline
\end{tabular}

Tabel 10

Gerbang Akar Pohon Diatas Bukit pada Scene-3

\begin{tabular}{ll}
\hline Signifier & $\begin{array}{l}\text { Merupakan representasi dari sebuah portal atau pintu gerbang menuju } \\
\text { perbedaan dimensi. (form) }\end{array}$ \\
\hline Signified & $\begin{array}{l}\text { Pintu masuk menuju kepada keberadaan ilahi, dengan penandaan adanya } \\
\text { mata yang terletak di tengah gerbang. (concept) }\end{array}$ \\
\hline Signification & $\begin{array}{l}\text { Untuk mencapai spiritualitas yang tinggi dapat dilakukan dengan } \\
\text { membuka dan meningkatkan intuisi yang ada dalam diri seseorang dan } \\
\text { keberadaan ilahi selalu berada di tempat tertinggi. }\end{array}$ \\
\hline
\end{tabular}

Tabel 3

Gitar yang Terbuat Dari Akar Pohon pada Scene-4

\begin{tabular}{ll}
\hline Signifier & $\begin{array}{l}\text { Merupakan representasi dari elemen-elemen alam seperti air dan bumi. } \\
\text { (form) }\end{array}$ \\
\hline Signified & $\begin{array}{l}\text { Menunjukkan bagaimana alam berkomunikasi, semua melodi yang kita } \\
\text { dengar berasal dari alam. (concept) }\end{array}$ \\
\hline Signification & $\begin{array}{l}\text { Sejatinya manusia dan alam memiliki keterkaitan yang tidak dapat } \\
\text { dipisahkan. }\end{array}$ \\
\hline
\end{tabular}

Tabel 4

Batu Melayang yang Membentuk Lingkaran pada Scene-5

\begin{tabular}{ll}
\hline Signifier & $\begin{array}{l}\text { Merupakan representasi dari cycle of life atau siklus kehidupan dan hal itu } \\
\text { berkaitan dengan spiritual journey setiap orang. (form) }\end{array}$ \\
\hline Signified & $\begin{array}{l}\text { Siklus kehidupan dari manusia yang berkaitan dengan perjalanan spiritual } \\
\text { dan batu-batuan merupakan elemen alam. (concept) }\end{array}$ \\
\hline Signification & $\begin{array}{l}\text { Setiap manusia harus merasakan perjalanan spiritualnya dengan } \\
\text { mendekatkan diri kepada "IBU" (alam). Batu yang membentuk lingkaran } \\
\text { dapat diartikan sebagai ekspresi spiritual atau perjalanan spiritual. }\end{array}$ \\
\hline
\end{tabular}

Tabel 5

Laki-Laki Berkulit Hitam pada Scene-6

\begin{tabular}{llllll}
\hline Signifier & Merupakan & representasi & dari keseimbangan siklus kehidupan, dan \\
\hline
\end{tabular}




\begin{tabular}{ll}
\hline & perspektif dualisme yaitu hitam atau putih, gelap atau terang. (form) \\
\hline Signified & $\begin{array}{l}\text { Mengembangkan kebijksanaan yang datang dari perspektif yang } \\
\text { melampaui dualitas baik atau buruk, hitam atau putih. (concept) }\end{array}$ \\
\hline Signification & $\begin{array}{l}\text { Manusia tidak akan bisa menghargai terang jika tidak ada gelap, dualisme } \\
\text { dapat membantu manusia untuk dapat melihat makna yang lebih dalam } \\
\text { dari situasi dalam kehidupan. }\end{array}$ \\
\hline
\end{tabular}

Tabel 6

Perempuan dengan Kudanya dan Anak-Anak pada Scene-7

\begin{tabular}{ll}
\hline Signifier & $\begin{array}{l}\text { Merupakan representasi dari seorang warrior atau pejuang, pendekar dan } \\
\text { pemimpin dan anak-anak merupakan representasi dari kemurnian, } \\
\text { kesucian atau purity. (form) }\end{array}$ \\
\hline Signified & $\begin{array}{l}\text { Seseorang yang menaiki kuda identik dengan seorang pejuang dan } \\
\text { pemimpin. Ketika manusia kembali ke alam sama halnya manusia tersebut } \\
\text { menjadi seperti anak-anak yang kembali kepada "IBU"nya (alam). } \\
\text { (concept) }\end{array}$ \\
\hline Signification & $\begin{array}{l}\text { Sejatinya anak-anak di dalam dirinya masih suci dan bersih dari hal-hal } \\
\text { buruk. }\end{array}$ \\
\hline
\end{tabular}

Pada penelitian terdahulu tidak sampai membahas mengenai penanda, petanda, makna denotatif, makna konotatif, dan mitos. Hanya saja penelitian terdahulu tersebut menganalisa beberapa bagian scene dari video klip lagu Man Upon The Hill dari Stars and Rabbit tidak menjelaskan mengenai representasi dari setiap scene yang mengandung unsur surealisme.

\section{SIMPULAN}

Berdasarkan analisa yang telah dilakukan oleh peneliti tentang representasi surealisme pada video klip Man Upon The Hill Stars and Rabbit, dengan menggunakan teori Roland Barthes terhadap makna dan mitos yang terdapat pada video klip tersebut dengan menganalisis visual pada setiap scene dengan menguraikan makna denotasi dan konotasi serta makna mitos pada video klip Man Upon The Hill Stars and Rabbit. Peneliti menggunakan kajian semiotika karena dengan semiotika peneliti dapat mengkaji lebih jauh untuk menemukan makna secara visual dalam setiap scene-nya. Selanjutnya, peneliti dapat mengambil kesimpulan bahwa konsep dari video klip tersebut yakni hubungan antar manusia dan alam. Terdapat dua entitas dalam konsep video klip Man Upon The
Hill Stars and Rabbit yaitu hubungan antar manusia dengan manusia dan hubungan manusia dengan alam. Representasi dari beberapa scene: Pertama, simbol seperti pentagram memiliki makna sebuah dimensi kehidupan. Kedua, Third Eye Chakra merupakan kesadaran tertinggi. Ketiga, susunan akar membentuk gerbang merepresentasikan gerbang menuju perbedaan dimensi. Keempat, gitar akar pohon mewakili bagaimana alam berkomunikasi, melodi yang terdengar berasal dari alam. Kelima, susunan batubatu melayang membentuk lingkaran merupakan siklus kehidupan. Keenam, kulit hitam merupakan representasi dari keseimbangan siklus kehidupan. Ketujuh, perempuan dengan kudanya merepresentasikan warrior, anak-anak merepresentasikan dari kemurnian.

Apabila menonton video klip diharapkan penonton bersikap kritis dan tidak langsung menerima apa adanya makna dari video klip yang disuguhkan pada setiap adegannya. Pada video klip Man Upon The Hill Stars and Rabbit pada adegan (scene) mata yang terletak di dahi (Third Eye Chakra), penonton hendaknya menggali arti dan makna yang sebenarnya yang terdapat pada scene tersebut, dengan 
kata lain video klip mampu menimbulkan banyak opini dan persepsi yang sangat dipengaruhi oleh tingkat kepahaman seseorang yang berasal dari pengalaman hidup dan pengetahuan yang dimiliki sehingga dapat menimbulkan opini dan persepsi yang salah.

\section{DAFTAR PUSTAKA}

Ainsyah S, P. (2019). Analisis Semiotika Roland Barthes Pada Video Klip Rehat Oleh Kunto Aji [skripsi]. Universitas Pasundan Bandung.

Anderson Daniel Sudarto, Jhony Senduk, M. R. (2015). Analisis Semiotika Film " Alangkah Lucunya Negeri Ini." Journal “Acta Diurna," IV(1), 1-14.

Anggy, R. (2019). Analisis Semiotika Pada Video Klip "Man Upon The Hill". Stars And Rabbit. Ejournal.Unp.ac.id.

Barthes, R. (2017). Elemen-Elemen Semiologi (T. E. A. Iyubenu, Ed., \& M.Ardiansyah (ed.)). BASABASI.

Eriyanto. (2001). Analisis Wacana: Pengantar Analisis Teks Media. Lkis.

KBBI. (2020). Kamus Besar Bahasa Indonesia (KBBI). http://kbbi.web.id/surealisme dan Diakses dari http://kbbi.web.id/videoklip

Kusuma, P. K. N., \& Nurhayati, I. K. (2019). Analisis Semiotika Roland Barthes Pada Ritual Otonan Di Bali.
Jurnal Manajemen Komunikasi, 1(2), 195.

https://doi.org/10.24198/jmk.v1i2.105 19

Lustyantie, N. (2012). Pendekatan Semiotika Model Roland Barthes dalam Karya Sastra Prancis. Seminar Nasional FIB UI, 1-15.

Pawito. (2007). Penelitian Komunikasi Kualitatif. Pelangi Aksara.

Piliang, A. Y. (2010). Hipersemiotika "Tafsir Cultural Studies Atas Matinya Makna." Jalasutra.

Pujileksono, S. (2015). Metode Penelitian Komunikasi: Kualitatif. Kelompok Intrans Publishing.

Sobur, A. (2017). Semiotika Komunikasi. Remaja Rosdakarya.

Sugiyono. (2016). Metode Penelitian: Kuantitatif, Kualitatif, dan $R \& D$. CV Alfabeta.

Thoriq, R. (2019). Representasi Makna Perjuangan Atas Keganasan Patriarki Dalam Film "Marlina Si Pembunuh Empat Babak." https://www.academia.edu/41265804/ Representasi_Makna_Perjuangan_Ata s_Keganasan_Patriarki_Dalam_Film

Wahyuningsih, S. (2019). Film Dan Dakwah: Memahami Representasi Pesan-Pesan Dakwah Dalam Film Melalui Analisis Semiotika". Media Sahabat Cendekia. 